\title{
Permasalahan Budaya Membaca di Indonesia (Studi Pustaka Tentang Problematika \& Solusinya)
}

\author{
Lilik Tahmidaten, Wawan Krismanto \\ lilik.tahmidaten@kemdikbud.go.id,wawan.krismanto@unm.ac.id \\ Kementerian Pendidikan \& Kebudayaan RI, Universitas Negeri Makassar \\ The Problems Of Reading Culture In Indonesia \\ (Literature Study About Problem \& Solutions)
}

\begin{abstract}
Reading is one of the language skills that must be mastered by every student, the ability to read becomes one of the mandatory components in the national education curriculum. However, assessment programs of various international institutions and the Ministry of Education \& Culture show that students in Indonesia are still low in their reading ability, in this case reading comprehension skills. For this reason, through this literature study, the problems and solutions are examined based on various library sources. The results of the literature study show that there are different standards between the teaching of reading in education in Indonesia and the standards used by various international institutions in measuring students' reading skills. In addition there are various factors driving the low ability \& reading culture of students in Indonesia, namely: 1) Reading has not become a necessity, let alone become a culture, 2) Misperception about the concept of reading ability in most societies including students and teachers, 3) Capacity building reading is still perceived as part of the responsibility of language courses only, 3) The learning process still does not utilize models, methods, learning strategies that are diverse and suitable for reading comprehension learning, 4) reading material, learning activities and practice / evaluation questions there are teaching materials in schools that tend to still dwell on low order thinking skills, 5) Not yet the maximum facilities and infrastructure of school libraries as a center for developing the ability and culture of reading students, and 6) Program of Gerakan Literasi Sekolah (GLS) has not shown the progress expected to build a reading culture.
\end{abstract}

Keywords: Reading Culture, Reading Comprehension, Literacy

\section{Article Info}

Received date: 27 Juli $2019 \quad$ Revised date: 3 September $2019 \quad$ Accepted date: 22 Januari 2020

\section{PENDAHULUAN}

Indonesia merupakan salah satu negara yang mengikuti Programme for International Student Assessment (PISA) yang dilakukan oleh organisasi negara-negara di dunia untuk kerjasama dan pembangunan ekonomi (Organisation for Economic Cooperation \& Development-OECD). PISA dilakukan pertama kali tahun 2000 dan data terakhir yang telah dipublikasikan adalah PISA 2018. Sejak ada pelaksanaan asessment tersebut, data-data tentang kemampuan membaca siswa di Indonesia menjadi begitu familiar bagi telinga masyarakat terutama kalangan pendidikan di Indonesia. Hal ini karena di setiap penyelenggaraannya, data-data PISA Result (termasuk yang terakhir), menempatkan Indonesia masih berada di kelompok bawah negara-negara yang mengikuti asessment tersebut (OECD, 2018). Hal ini membuat masyarakat selalu memperhatikan hasilnya, salah satunya adalah data tentang Reading atau kemampuan membaca siswa Indonesia. Selain itu, studi lainnya oleh Progress in International Reading Literacy Study (PIRLS) dan Early Grade Reading Assessment (EGRA) (Mullis \& Martin, 2017; (USAID) Indonesia, 2014) yang ternyata menunjukkan data yang tidak jauh berbeda dari PISA. Data lain tentang kemampuan membaca yang kemudian ramai diperbincangkan bahkan menjadi kontroversi adalah data dari World's Most Literate Nations yang dilakukan oleh Central Connecticut State University Amerika Serikat yang dirilis pada awal tahun 2017, dimana Indonesia menempati urutan ke-60 dari 61 negara partisipan survei dalam hal kemampuan literasi (Central 
Connecticut State University, 2017). Hasil Indonesia National Assesment Program di tahun 2016 yang dilakukan oleh Pusat Penelitian Pendidikan (Puspendik) Kementerian Pendidikan \& Kebudayaan sendiri mengungkap data bahwa rata-rata nasional distribusi literasi pada kemampuan membaca pelajar di Indonesia adalah 46,83\% berada pada kategori Kurang, hanya 6,06\% berada pada kategori Baik, dan 47,11 berada pada kategori Cukup (P. Kemdikbud, 2017).

Memperhatikan data-data di atas, sebagian kalangan menganggap itu semua merupakan sebuah permasalahan, bahkan dianggap gawat darurat dan menjadi bukti kuat adanya "penyakit-penyakit" kronis dalam penyelenggaraan pendidikan di Tanah Air (Driana, 2012), sebab data-data tersebut menunjukkan salah satu kelemahan serius bangsa Indonesia setelah lebih dari 70 tahun merdeka. Bagi sebagian kalangan lain, data-data tersebut menjadi sebuah kontroversi dengan mempertanyakan berapa jumlah sampel yang diambil, seberapa luas wilayah dan daerah yang di survei, mengingat besarnya jumlah siswa dan luasnya wilayah dengan disparitas kualitas pendidikan di Indonesia yang masih tinggi. Namun demikian, entah dianggap sebagai permasalahan ataupun kontroversi, sebagian menganggap bahwa data rendahnya kemampuan dan budaya membaca di Indonesia hendaknya dijadikan dasar untuk berpikir positif karena bagaimanapun juga survei-survei tersebut dilakukan dengan metodologi dan publikasi secara ilmiah yang tentu saja dapat dipertanggungjawabkan keilmiahannya oleh pihak penyelenggaranya. Dengan berpikir positif maka data-data tersebut dapat dijadikan bahan refleksi dan evaluasi semua pihak yang terkait dengan pendidikan untuk perbaikan kedepannya, khususnya yang terkait langsung dengan peningkatan kemampuan dan budaya membaca untuk peningkatan daya baca bangsa (Ibrahim, 2017). Langkah refleksi dan evaluasi penting dilakukan mengingat membaca memiliki posisi serta peran yang sangat penting dalam konteks kehidupan umat manusia, terlebih pada era informasi dan komunikasi seperti sekarang ini. Membaca juga merupakan sebuah jembatan bagi siapa saja dan di mana saja yang berkeinginan meraih kemajuan dan kesuksesan, baik di lingkungan dunia persekolahan, pekerjaan maupun sepanjang kehidupan umat manusia. Oleh karena itu, para pakar sepakat bahwa kemahiran membaca (reading literacy) merupakan conditio sine quanon (prasyarat mutlak) bagi setiap insan yang ingin memperoleh kemajuan (Harras, 2014). Oleh karena itu, beberapa hal yang kiranya perlu dikaji adalah: 1) apa standar yang sebenarnya digunakan oleh survei-survei internasional tentang kemampuan membaca?, 2) faktor apa yang menyebabkan budaya membaca pelajar Indonesia masih belum ada perkembangan yang signifikan? dan 3) langkah apa yang perlu dilakukan/diperbaiki untuk membangun budaya membaca?. Untuk itu artikel ini berusaha membahas dalam ruang lingkup ketiga hal tersebut berdasarkan literatur-literatur yang digunakan dalam studi pustaka ini.

\section{KAJIAN PUSTAKA}

Membaca adalah salah satu dari empat keterampilan berbahasa. Membaca adalah suatu proses yang dilakukan serta dipergunakan oleh pembaca untuk memperoleh pesan, yang hendak disampaikan oleh penulis melalui media kata-kata/bahasa tulis. Membaca sebagai salah satu aspek keterampilan berbahasa yang mengandung pengertian yang tidak selalu sama bagi setiap orang, ada yang memandang membaca sebagai proses pasif, ada pula yang menyatakan bahwa membaca merupakan proses aktif kognitif. Akan tetapi membaca pada hakikatnya adalah kemampuan melafalkan lambang-lambang bunyi bahasa dan memahami maknanya. Membaca pada hakikatnya adalah suatu yang rumit yang melibatkan banyak hal, tidak hanya sekedar melafalkan tulisan, tetapi juga melibatkan aktivitas visual, berpikir, psikolinguistik, dan metakognitif. Sebagai proses visual membaca merupakan proses menerjemahkan simbol tulis (huruf) ke dalam kata-kata lisan. Sebagai proses berpikir, membaca mencakup aktivitas pengenalan kata, pemahaman literal, interpretasi, membaca kritis, dan pemahaman kreatif (Rahim, 2008). Sejalan dengan itu Finonchiaro mendefinisikan bahwa membaca sebagai suatu usaha memetik dan memahami makna yang terkandung dalam bahasa tertulis baik makna yang tersirat dengan cara memproses informasi, silabas, sintaksis dan semantik (Tarigan, 2008).

Di samping pengertian yang diutarakan di atas, membaca pun dapat diartikan sebagai suatu metode yang kita gunakan untuk berkomunikasi dengan diri kita sendiri dan kadang-kadang dengan orang lain yaitu mengkomunikasikan makna yang terkandung atau tersirat pada lambang-lambang tertulis. Membaca dapat pula dianggap sebagai suatu proses untuk memahami yang tersirat dalam yang tersurat, melihat pikiran yang terkandung di dalam kata-kata yang tertulis. Tingkatan hubungan antara makna yang hendak dikemukakan oleh penulis dan penafsiran atau interprestasi pembaca turut 
menentukan ketepatan membaca. Berdasarkan beberapa pendapat tersebut, dapat disimpulkan bahwa membaca pada hakikatnya adalah suatu kegiatan atau proses yang dilakukan oleh pembaca untuk menerjemahkan dan membangun makna dari pesan yang disampaikan oleh tulisan atau teks.

Dalam membaca sangat penting adanya kemampuan untuk mengerti apa yang sedang dibaca, dan apa yang sedang dan ingin diketahui dalam membaca suatu teks/bacaan. Hal inilah yang disebut sebagai pemahaman akan bacaan. Pemahaman dapat diartikan kemampuan yang melibatkan pikiran dan analisis siswa. Kegiatan memahami sesuatu hal dilakukan oleh siswa dengan kemampuan kognitifnya berusaha menangkap makna dari apa yang tengah dihadapi atau dipelajari. Membaca merupakan suatu keterampilan untuk meningkatkan daya nalar seseorang. Artinya, dalam membaca pastinya ada informasi yang dapat kita peroleh yang fungsinya menambah wawasan yang kita miliki. Tetapi dalam memperoleh informasi tersebut. Tentunya dalam membaca harus beriringan dengan pemahaman tentang apa yang kita baca. Dalam hal ini Finochiaro dan Bonomo berpendapat bahwa membaca adalah bringing meaning to and getting meaning from printed or written material, dengan kata lain membaca tidak hanya sekedar melafalkan kata dan kalimat namun memetik serta memahami arti atau makna yang terkandung di dalam bahasa tertulis" (Harras, 2014). Hal senada juga dituturkan oleh Lado bahwa "membaca tidak hanya kegiatan yang dilakukan dengan mengucapkan apa yang kita lihat tetapi membaca pemahaman adalah memahami pola-pola bahasa dari gambaran tertulisnya" (Tarigan, 2008)..

Dalam kegiatan memaknai bacaan, pembaca akan melibatkan ranah kognitif, berusaha memikirkan, menganalisis dan mengerti tentang apa yang dibacanya. Atau dapat dikatakan bahwa membaca pemahaman, adalah kegiatan membaca yang dilakukan dengan melibatkan ranah kognitif untuk memikirkan, menganalisa dan akhirnya mengerti atau memahami bahan bacaan. Dalam membaca pemahaman, diharapkan dapat diperoleh pemahaman sebaik-baiknya mengenai isi dari apa yang dibaca. Dalam hal ini Herber dan Nelson membagi level pemahaman menjadi tiga level, yakni level literal, level interpretive, dan applied (Rahim, 2008). Pemahaman literal, adalah pemahaman dimana informasi yang diperoleh dari bacaan, yang persis sama dengan teks atau bacaan. Level ini merupakan modal awal untuk menuju ke level pemahaman selanjutnya. Pemahaman interpretative, adalah pemahaman yang diperoleh oleh penafsiran gagasan-gagasan atau informasi yang ada dalam teks. Dengan kata lain pemahaman level interpretative mengacu pada proses menentukan maksud dari apa yang tertulis dalam teks, atau mengacu pada penemuan pesan yang implisit yang terkandung dalam teks. Pemahaman level applied, adalah pemahaman yang diperoleh melalui proses sintesis dari berbagai gagasan dan informasi, baik yang bersumber dari dalam teks maupun yang bersumber dari luar teks. Dengan mengadakan sintesis tersebut pembaca sudah memperoleh kesimpulan dari apa yang dibacanya. Agar sampai pada pemahaman ini, pembaca dituntut mengadakan pengombinasian antara informasi teks dengan skemata pembaca.

Membaca pemahaman berkaitan erat dengan usaha memahami hal-hal penting dari apa yang dibacanya. Membaca pemahaman atau komprehensif adalah kemampuan membaca untuk mengerti ide pokok, detail penting, dan seluruh pengertian. Pemahaman ini berkaitan erat dengan kemampuan mengingat bahan yang dibacanya. Berdasarkan pengertian tersebut, ada tiga hal atau tiga elemen dalam membaca pemahaman, yaitu: 1) Pengetahuan dan pengalaman yang telah dimiliki tentang topik, 2) Menghubungkan pengetahuan dan pengalaman dengan teks yang akan dibaca, dan 3) Proses pemerolehan makna secara aktif sesuai dengan pandangan yang dimiliki. Selaras dengan itu, Gufran A. Ibrahim menjelaskan bahwa ada tiga hal penting terkait daya baca, yaitu kemampuan menukik ke kedalaman teks, ketahanan menjaga fokus, dan pemeliharaan nalar untuk terus mengikuti bangunstruktur teks, terus mengenali keragaman tipologi dan kompleksitas teks. Tiga-tiganya memberi kontribusi pada efisiensi pemanfaatan waktu uji dan keberhasilan menukik ke kedalaman teks kemudian menangkap makna bacaan (Ibrahim, 2017).

Membaca adalah suatu proses yang dilakukan serta dipergunakan oleh pembaca untuk memperoleh pesan, yang hendak disampaikan oleh penulis atau pesan yang bertujuan untuk menambah wawasan/pengetahuan bagi pembacanya. Menurut Rahim membaca pemahaman bertujuan untuk menemukan pesan implisit dalam teks bacaan, selajutnya dari kegiatan membaca pemahaman pembaca dapat memperoleh pemahaman yang baik dan mengaplikasikan pengetahuan yang diberitahukan oleh teks dengan melalui proses sintesis dari berbagai gagasan dan informasi, baik yang bersumber dari dalam teks maupun bersumber dari luar teks (Rahim, 2008). Dengan mengadakan sintesis tersebut pembaca sudah memperoleh simpulan dari apa yang dibacanya. Penemuan atas pesan implisit dalam 
teks tersebut merupakan tujuan dari membaca pemahaman. Tujuan yang lain, dari membaca pemahaman, pembaca memperoleh pemahaman yang baik dan mengaplikasikan pengetahuan yang diberitahukan oleh teks dengan melalui proses sintesis dari berbagai gagasan dan informasi, baik yang bersumber dari dalam teks, maupun bersumber dari luar teks.

\section{METODE PENELITIAN}

Penelitian ini merupakan penelitian kualitatif yang bersifat studi pustaka (library research) dengan menggunakan sumber data berupa buku-buku referensi dan artikel-artikel jurnal ilmiah. Pada penelitian ini rangkaian kegiatannya berkenanaan dengan pengumpulan data pustaka, membaca dan mencatat, lalu mengolah informasi yang sesuai dan diperlukan untuk menjawab rumusan masalah yang akan dipecahkan. Adapun prosedur yang dilakukan pada penelitian studi pusataka ini meliputi: 1) menggali ide umum tentang penelitian, 2) mencari informasi yang mendukung topik penelitian, 3) mempertegas fokus penelitian dan mengorganisasi bahan yang sesuai, 4) Mencari dan menemukan sumber data berupa sumber pustaka utama yaitu buku dan artikel-artikel jurnal ilmiah, 5) melakukan re-organisasi bahan dan catatan simpulan yang didapat dari sumber data, 6) melakukan review atas informasi yang telah dianalisis dan sesuai untuk membahas dan menjawab rumusan masalah penelitian, 7) memperkaya sumber data untuk memperkuat analisis data dan 8) menyusun hasil penelitian.

\section{HASIL PENELITIAN DAN PEMBAHASAN}

\section{Standar Asessmen Internasional Dalam Mengukur Kemampuan Membaca}

Sebuah analisa tentang pengukuran kemampuan membaca dilakukan oleh Gufran A. Ibrahim selaku Ketua Pokja Literasi Membaca Menulis, Gerakan Literasi Nasional, Kementerian Pendidikan \& Kebudayaan (Ibrahim, 2017), yaitu:

Pertama, teks bacaan dalam uji PISA adalah multiteks yang sajiannya begitu canggih. Isi dan struktur teksnya dalam tampilan beragam genre wacana dengan memadukan kata, kalimat, grafik, peta, dan ragaan yang dibentuk dalam tautan lintas-teks dengan siasat rujuk silang (cross-reference). Untuk menukik ke kedalaman makna multiteks seperti ini, sedikitnya dibutuhkan dua kecakapan penting: (1) terampil menangkap makna yang tersaji dalam paragraf; dan (2) kecepatan mengemas tautan makna antarteks, antarteks dengan grafik, antarteks dan simbol, serta relasi makna antargrafik.

Kedua, jika hanya terbiasa berhadapan dengan teks tunggal di sekolah, yaitu teks hanya rangkaian paragraf, siswa kita akan kesulitan luar biasa menghadapi teks ragam genre dalam kemasan multimedia. Siswa yang hanya terbiasa membaca sebagai "cara menyandikan kembali lambanglambang ortografi secara diam atau nyaring" akan "kewalahan" menghadapi teks kompleks yang disodorkan uji PISA. Apabila siswa kita tak menjadikan membaca sebagai aktivitas harian, di sekolah ataupun di rumah, kepayahan akan menghadang saat menghadapi rumitnya struktur fisik dan kedalaman makna multiteks dalam kemasan multimedia. Apalagi jika siswa membaca hanya kalau ada tugas sekolah. Belum lagi pembelajaran di kelas yang tidak mendorong strategi membaca yang variatif dan eksploratif serta inovasi model membaca yang mengenalkan keragaman genre teks. Kalau benar siswa yang jadi sasaran uji PISA tak terbiasa mengenali dan membaca teks kompleks, maka gagal paham atas "rimba" semantik multiteks sebenarnya bersumber dari persoalan yang sederhana tapi mendasar dalam belajar, yaitu ihwal "kebiasaan" dan "kebisaan". Kalau saja belajar didefinsikan secara sederhana sebagai aktivitas psikokognitif siswa "membiasakan" tindakan pemerolehan pengetahuan-kecakapanketerampilan, maka kepandaian dan kesuksesan menukik ke kedalaman teks-teks multigenremultimedia dan menangkap spektrum maknanya hanya akan bisa dibentuk melalui "pembiasaan" mengenali dan membaca teks-teks tersebut. Jika kelas di sekolah hanya bisa dan biasa membelajarkan membaca teks-teks tunggal dan sederhana yang nir-inovasi, siswa hanya akan bisa mencapai kepandaian setingkat itu: kemampuan baca paling dasar.

Studi lain tentang instrumen PISA dilakukan oleh Harsiati yang bertujuan menelaah karakteristik soal membaca instrumen PISA tahun 2000-2009 (Harsiati, 2018), dimana hasil analisisnya adalah sebagai berikut:1) Soal literasi membaca PISA didominasi keterampilan berpikir tingkat tinggi berupa kemampuan interpretasi, refleksi, dan evaluasi. 2) Kemampuan membaca yang diujikan adalah mengungkapkan kembali informasi, mengembangkan interpretasi dan mengintegrasikan, serta merefleksikan dan mengevaluasi teks. 3) Soal cenderung menggunakan wacana panjang (135-630 kata) dan kalimat pertanyaan cenderung kompleks. 4) Ragam tes yang digunakan meliputi pilihan ganda, 
pilihan ganda kompleks, jawaban singkat, esai tertutup, dan esai terbuka. 5) Karakteristik konteks diklasifikasikan empat kategori, yaitu pendidikan, pekerjaan, personal, dan masyarakat. 6) Isi kutipan bertema keselamatan keamanan diri, bermasyarakat, cara menyelesaikan pendidikan dan IPTEK, cerita personal berisi nilai moral untuk meningkatkan kualitas hidup.

Berdasarkan dua studi yang pada intinya menyimpulkan hal yang sama, maka dapat disimak bahwa untuk dapat menyelesaikan soal-soal yang ada pada instrumen PISA membutuhkan kemampuan dan keterampilan membaca pemahaman yang tidak hanya sekedar mampu membaca teks soal dan wacana yang disediakan. Persoalan yang dihadapi oleh para siswa Indonesia adalah mereka terbiasa dengan wacana yang sederhana dengan penilaian atau bentuk soal yang sederhana pula atau sering diistilahkan dengan low order thinking. Dalam hal ini kemampuan para penulis buku ajar, penyusun soal dan juga guru dalam memfasilitasi dan membiasakan siswa dengan bacaan dan soal yang high order thinking sangat dibutuhkan. Dalam hal ini Widiningsih menjelaskan bahwa wacana dan penilaian yang berorientasi high order thinking akan mengarahkan pada proses pembentukan keterampilan dalam hal : 1) transfer satu konsep ke konsep lainnya, 2) memproses dan mengintegrasikan informasi, 3) mencari kaitan dari berbagai informasi yang berbeda-beda, 4) menggunakan informasi untuk menyelesaikan masalah, dan 5) menelaah ide dan informasi secara kritis (Widiningsih, 2019). Dengan demikian soal-soal HOTS menguji keterampilan berpikir menganalisis, mengevaluasi, dan mencipta. Untuk membiasakan maka perlu waktu sehingga membiasakannya sejak usia dini atau sekolah dasar menjadi sebuah keharusan. Artinya peningkatan kemampuan membaca haruslah dididukung oleh budaya membaca yang baik.

\section{Faktor Pendorong Rendahnya Kemampuan \& Budaya Baca Siswa di Indonesia}

a. Salah persepsi tentang konsep kemampuan membaca pada sebagian besar masyarakat termasuk siswa dan guru.

Hal ini menjadi salah satu faktor yang masih saja terjadi, misalnya pembelajaran membaca pada tingkat Sekolah Dasar yang seharusnya menjadi pondasi awal membangun kemampuan membaca yang cenderung abai terutama setelah siswa menginjak kelas tinggi. Faktor yang melatarbelakangi karena anggapan yang salah baik pada orang tua maupun guru terhadap kemampuan membaca itu sendiri. Orang tua, guru dan masyarakat pada umumnya, menganggap bahwa pengajaran membaca telah berakhir ketika seorang siswa Sekolah Dasar telah mampu membaca dan menulis permulaan yang biasanya dilaksanakan di kelas I dan II Sekolah Dasar. Sementara pada jenjang yang lebih tinggi, yaitu kelas III sampai kelas VI, pengajaran membaca lanjut (membaca pemahaman) belum mendapat perhatian yang serius dalam arti belum dimulai ditanamkan secara kontinyu, sehingga membaca di kelas tinggi tersebut seolah-olah masih menekankan pada kegiatan membaca nyaring dan lancar yang merupakan lanjutan dari membaca dan menulis permulaan di kelas I dan II Sekolah Dasar (Krismanto, Halik, \& Sayidiman, 2015).

b. Pengembangan kemampuan membaca masih dipersepsikan sebagai bagian dari tanggung jawab mata pelajaran bahasa saja.

Berdasar perspektif kurikulum memang benar bahwa membaca adalah salah satu kompetensi yang harus diajarkan dalam mapel bahasa, sehingga guru mata pelajaran lain merasa tidak perlu ikut serta mengembangkan kemampuan membaca pemahaman. Padahal pada semua mata pelajaran siswa harus membaca materi dan disitulah semua guru mata pelajaran hendaknya ikut berperan. Misal guru mapel matematika sangat berperan dalam mengembangkan kemampuan siswa membaca grafik, tabel dan diagram, guru mapel IPS mengembangkan kemampuan siswa membaca denah, peta, guru mapel IPA mengembangkan kemampuan membaca prosedur, dsb.

c. Proses pembelajaran sekolah dasar masih belum memanfaatkan model, metode, strategi dan media pembelajaran yang beragam dan sesuai untuk pembelajaran membaca pemahaman

Secara metode pembelajaran maupun bahan ajar yang digunakan di sekolah masih belum memfasilitasi pengajaran membaca pemahaman. Model pembelajaran masih monoton pada kegiatan membaca bacaan lalu menjawab soal dibawah bacaan atau LKS, sehingga aktivitas pembelajaran membaca menjadi membosankan dan cenderung tidak menarik. Padahal begitu banyak model, metode strategi dan media pembelajaran membaca pemahaman yang sebenarnya bisa digunakan oleh guru dalam mengajarkan kemampuan membaca pemahaman dan banyak yang telah mengkaji dan 
mengujinya seperti SQ3R (Krismanto et al., 2015), Latihan Terbimbing (Boliti, 2017), Model Reciprocal Teaching (Noriasih, 2013), Pendekatan SAVI (Sari, Winarni, \& Daryanto, 2014), Model CIRC (Tristiantari \& Sumantri, 2017), strategi KWL (Aryani, Samadhy, \& Sismulyasih, 2012), pengunaan media Big Book (Setiyaningsih \& Syamsudin, 2019) dll.

d. Bahan bacaan, kegiatan pembelajaran dan soal-soal latihan/evaluasi yang ada pada bahan ajar di sekolah cenderung masih berkutat pada keterampilan berpikir tingkat rendah (low order thinking)

Salah satu elemen perubahan pada kurikulum 2013 adalah penguatan proses pembelajaran dan berpikir tingkat tinggi, namun pada kenyataannya masih banyak guru yang kurang paham tentang hal ini. Seharusnya guru mampu mengembangkan dan mengkonversikan dari pembelajaran yang masih bersifat Lower Order Thinking Skill (LOTS) menjadi Higher Order Thinking Skill (HOTS), dan ini harus sudah diawali sejak merancang Rencana Pelaksanaan Pembelajaran (RPP) (Fanani \& Kusmaharti, 2018). Salah satu hal yang terlihat adalah dari kualitas bacaan dan pengalaman belajar dan soalnya. Pada umumnya soal-soal masih berkutat pada pertanyaan faktual yang menugaskan siswa untuk mencari tahu: apa, siapa, kapan, di mana, tidak sampai pada: apa yang terjadi, mengapa terjadi, apa yang terjadi jika ... dan sebagainya. Bahkan sangat minim bacaan-bacaan kelas 4-6 SD yang menghadirkan peta, grafik, tabel. Jika pun ada maka pertanyaannya masih bersifat tekstual dan visual yang ada pada peta, grafik dan tabel, belum sampai pada memaknai data dibalik visualisasi data. Sementara soal-soal yang ada pada instrumen PISA, PIRLS dan EGRA berbentuk soal HOTS. Harsiati menjelaskan bahwa dari segi aspek kompetensi membaca yang diukur, soal literasi membaca PISA memiliki karakteristik berfokus pada kemampuan berpikir tingkat tinggi. Pada soal membaca PISA aspek kompetensi membaca dikategorikan tiga jenis yang mencakup: (a) kemampuan mengungkapkan kembali informasi (retrieving Information),(b) mengembangkan interpretasi (developing an interpretation), (c) merefleksikan dan mengevaluasi teks (Harsiati, 2018). Sebagai contoh:

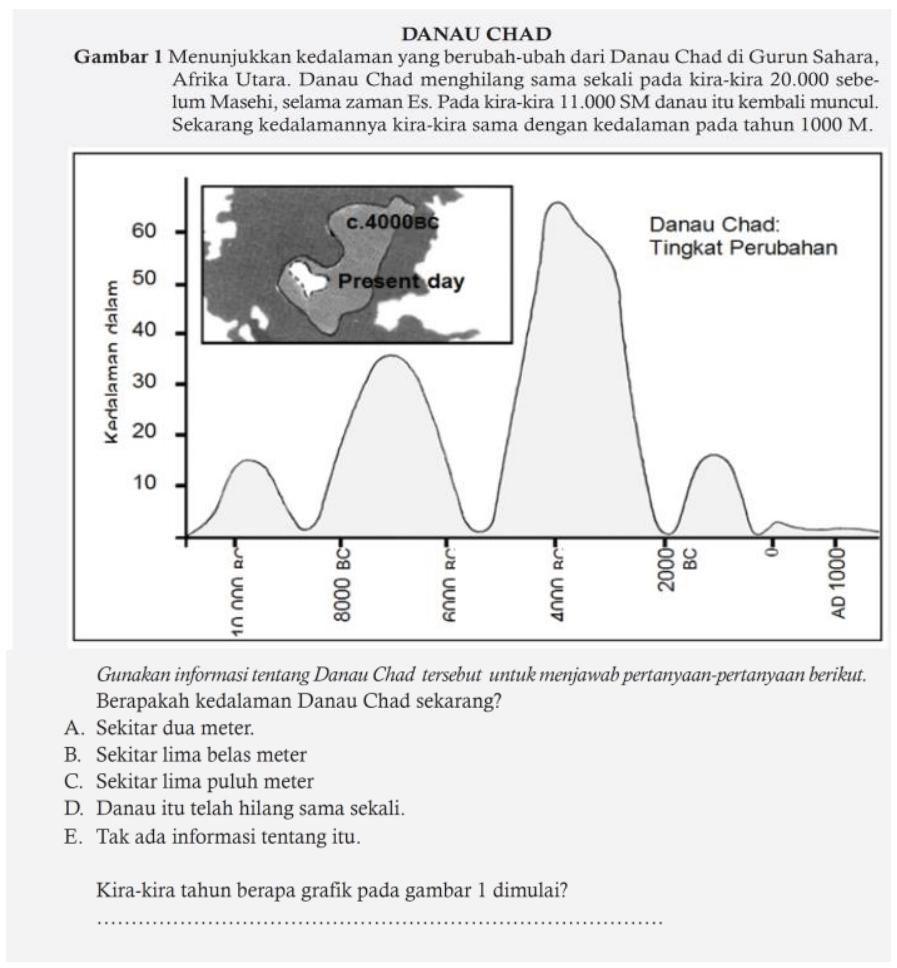

e. Belum maksimalnya sarana prasarana dan pelayanan perpustakaan sekolah sebagai pusat pengembangan kemampuan membaca siswa.

Bersumber dari data BPS 2017, secara umum, ketersediaan perpustakaan belum mencapai seratus persen bahkan kurang dari 80 persen. Jika diasumsikan 1 sekolah 1 perpustakaan, maka berdasarkan data maka 2 dari 10 SD tidak memiliki perpustakaan. Angka tersebut turun menjadi 3 pada jenjang SMP dan SMA, bahkan pada jenjang SMK, hanya 6 dari 10 sekolah tersedia perpustakaan (BPS, 2017). Sehingga bagaimana mau mengembangkan kemampuan membaca apalagi membudayakan 
membaca, jika sekolahnya saja belum memiliki perpustakaan. Membahas tentang peran perpustakaan maka harus melihat dari 4 sisi yakni: 1) fasilitas, 2) administrasi pengelolaannya, 3) sumber daya manusia pengelolanya dan 4) program-program pemanfaatan perpustakaan untuk mendukung gerakan membaca (literasi sekolah). Berdasarkan data hasil survei sederhana di sebuah kota di Sulawesi Selatan yang dilakukan Krismanto pada sekolah-sekolah yang memiliki perpusatakaan, hanya sisi fasilitaslah yang berada dalam kategori cukup baik, dalam arti memiliki ruangan tersendiri (meski ada yang digabung dengan ruang lain), koleksi lebih dari 500 buku, fasilitas rak buku tersedia dan ada penambahan koleksi setiap tahun. Namun untuk tata kelola perpustakaan, sumber daya manusia pengelolanya dan ketersediaan program-program pemanfaatan perpustakaan untuk mendukung gerakan literasi sekolah masih berkategori kurang baik bahkan dapat dikatakan memprihatinkan (Krismanto, 2017).

Pengelolaan perpusatakaan seringkali diabaikan, mulai dari tidak diprioritaskannya pemilihan ruangan gedung perpustakaan (biasanya mendahulukan kepentingan ruang kepala sekolah/ruang guru), abai atas penataan ruangan, penataan rak dan buku koleksi, tata pencahayaan dan dekorasi yang membuat siswa tidak tertarik dan tidak merasa nyaman di perpustakaan, sampai pada minimnya program perpustakaan untuk menarik minat siswa datang dan berlama-lama membaca di perpustakaan. Beberapa kali observasi didapatkan kondisi yang memprihatinkan dimana perpustakaan sekolah diletakkan pojok paling belakang, dengan ruangan sempit bahkan ada yang digabung dengan gudang atau dapur, tata ruang apa adanya bahkan ada yang mirip dengan gudang, penataan buku yang ditumpuk begitu saja (bahkan ada yang masih tertutup rapat dalam kardus), pencahayaan yang tidak terang dan dekorasi yang apa adanya dan cenderung tidak menarik. Sekolah juga tidak memiliki program untuk memanfaatkan perpustakaan secara rutin, inisiatif guru untuk mendorong siswa datang dan membaca di perpustakaan dengan mengintegrasikan pada kegiatan pembelajaran juga minim, apalagi program yang memacu dan menantang siswa untuk membaca juga tidak ada. Hal yang lebih memprihatinkan adalah ketika perpustakaan dijadikan ruangan "menghukum" siswa ketika terlambat, tidak mengerjakan PR atau kenakalan siswa lainnya. Berikut beberapa contoh kondisi tersebut seperti yang ada pada beberapa sekolah yang pernah diobservasi.
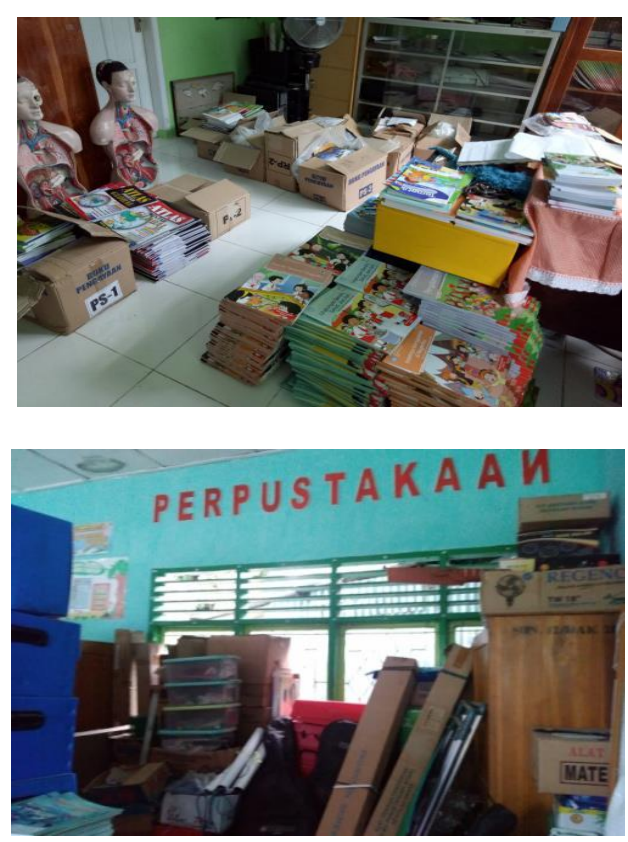
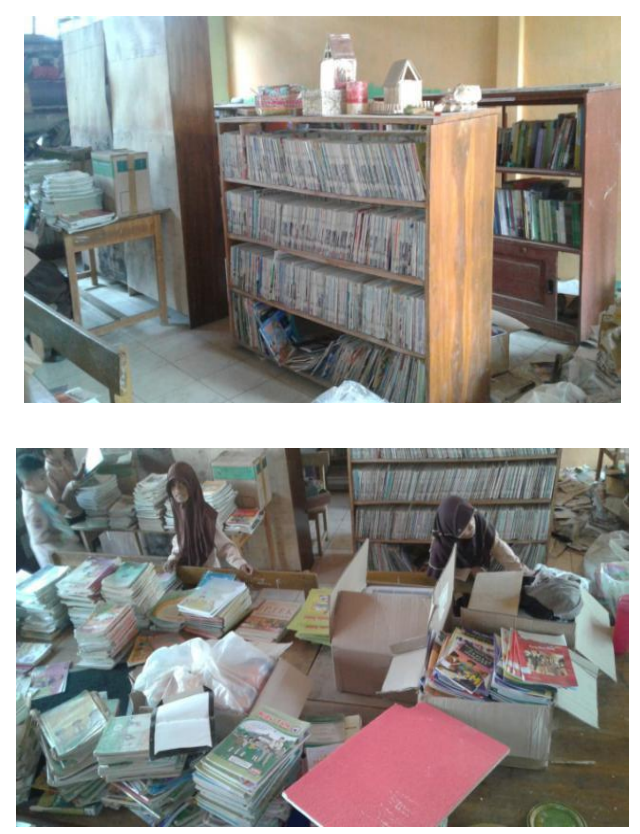

Gambar 1. Beberapa contoh kondisi perpustakaan sekolah yang kurang representatif Sumber: dokumentasi pribadi

7) Program Gerakan Literasi Sekolah (GLS) yang masih belum memperlihatkan progres yang diharapkan

Kementerian Pendidikan dan Kebudayaan telah berupaya dengan membuat kebijakan terkait dengan budaya membaca. Kebijakan tersebut antara lain adalah Peraturan Menteri Pendidikan dan 
Kebudayaan Nomor 21 Tahun 2015 tentang Penumbuhan Budi Pekerti, salah satunya, mengenai kegiatan membaca buku nonpelajaran selama lima belas menit sebelum waktu belajar dimulai. Kegiatan tersebut adalah upaya menumbuhkan kecintaan membaca kepada peserta didik dan pengalaman belajar yang menyenangkan sekaligus merangsang imajinasi. Sebagai turunan peraturan menteri tersebut telah disosialisasikan pula pada seluruh sekolah di Indonesia tentang Gerakan Literasi Sekolah, meliputi 3 tahapan yakni: 1) penumbuhan minat baca, 2) meningkatkan kemampuan literasi buku pengayaan dan 3) meningkatkan kemampuan literasi buku pelajaran (D. D. Kemdikbud, 2016). Namun demikian, berdasarkan sebuah survei yang dilakukan di awal 2017, dari 24 sekolah dasar yang disurvei di sebuah kota, hanya 33\% yang rutin melaksanakan sesuai dengan panduan gerakan literasi sekolah. Bahkan masih terdapat $33 \%$ sekolah yang belum pernah melakukan program implementasi gerakan literasi sekolah sesuai panduan dan selebihnya pernah melaksanakan namun tidak rutin (Krismanto, 2017).

Pekerjaan rumah yang cukup berat sesungguhnya untuk menggerakkan literasi pada bangsa ini, namun sepertinya belum menjadi sebuah gerakan nasional yang benar-benar tumbuh dari hati. Dari sisi eksekutif dan legislatif masih sekedar mengeluarkan kebijakan dan regulasi, sementara gerakan masifnya masih setengah hati. Pihak sekolah juga setali tiga uang, dari beberapa observasi, banyak sekolah dengan pagar dan gerbang yang mewah, dinding kelas berkeramik, ruang guru dan kepala sekolah yang luas dan nyaman namun perpustakaan sungguh menyedihkan baik isi, pengelolaan dan programnya. Masyarakat demikian pula, belum memiliki kesadaran penuh atas pentingnya gerakan literasi dalam kehidupan sehari-harinya, misal gerakan mematikan televisi yang diubah menjadi membaca dan belajar pada jam 18.00-21.00 yang sempat ramai diberitakan ternyata hanya ditempat tertentu saja dan belum juga merambah dan meluas. Maka ini juga menjadi problem dan berimplikasi pada rendahnya kemampuan dan budaya baca di Indonesia.

\section{Upaya Perbaikan yang Perlu Dilakukan}

Demi tumbuhnya daya baca bangsa yang akan ditandai dengan kemampuan dan budaya membaca yang baik, maka kesuksesan program Gerakan Literasi sudah menjadi keharusan agar membaca tidak lagi menjadi permasalahan apalagi kontroversi, namun membaca menjadi solusi atas segala permasalahan bangsa. Untuk kesuksesan tersebut banyak hal yang perlu segera diperbaiki. Gufran A. Ibrahim mengungkapkan bahwa paling tidak ada dua cara penting untuk meningkatkan budaya literasi membaca. Menurutnya hal tersebut tentu tak sekadar untuk kepentingan penilaian PISA atau program-program asessmen kemampuan membaca lainnya, tetapi yang paling penting adalah memastikan pelaksanaan pelajaran membaca benar-benar dibangun untuk membentuk daya baca. Pertama, menemu-kenali sebab-sebab terdalam mengapa siswa kurang sabar dan kurang cermat saat berhadapan dengan teks yang panjang dan dalam uji PISA. Kedua, kita merumus-ulang paradigma pembelajaran membaca, tidak hanya melalui mata pelajaran bahasa (Indonesia dan Inggris), tetapi menyusun model pembelajaran membaca bagi seluruh mata pelajaran. Semua guru mata pelajaran di sekolah dilatih model dan strategi membaca melalui model pembelajaran andragogi, dengan tiga siasat penting: (1) pencanggihan cara membaca; (2) peragaman jenis-jenis teks, dari teks tertulis - berbasis kertas (paper base) - yang sederhana hingga teks kompleks; dan (3) pengenalan teks-teks multimedia berbasis komputer-nirkertas (paperless) (Ibrahim, 2017). Untuk itu perbaikan kualitas pembelajaran membaca, bahan ajarnya, kualitas latihan dan soal-soal evaluasinya perlu segera dilakukan yang tentunya melibatkan banyak pihak terkait. Dengan demikian para pelajar Indonesia tidak terpaku dan terbiasa pada wacana-wacana yang low order thinkings.

Berikutnya adalah perbaikan sarana prasarana atau keberadaan perpustakaan sekolah sebagai pusat literasi, tidak hanya literasi warga sekolah namun warga masyarakat disekitarnya untuk mendukung kebiasaan gemar membaca siswa dan warga masyarakat sekitar. Selain itu tata kelola dan program kerja perpustakaan perlu dibangun seiring dengan penyediaan sarana-prasatana perpustakaan sekolah. Satuan pendidikan merupakan wahana paling tepat untuk menumbuhkan kegemaran membaca sejak usia dini yang terus dikembangkan sejalan dengan peningkatan kemampuan peserta didik, antara lain, melalui penugasan kepada mereka untuk mendayagunakan bahan bacaan yang tersedia di perpustakaan (UU No. 43 Tahun 2007 tentang perpustakaan, Penjelasan Pasal 51 Ayat 3). Oleh karena itu, upaya meningkatkan jumlah perpustakaan sekolah perlu dilakukan pemerintah dan harus memastikan tidak ada satu pun sekolah di Indonesia yang tidak memiliki perpustakaan. Pendampingan tata kelola dan pengembangan program literasi yang berpusat pada perpustakaan sekolah perlu 
diintensifkan, dengan demikian sarana prasarana yang dibangun dapat memberi kontribusi yang maksimal pada peningkatan kemampuan membaca dan budaya membaca.

Selain itu, Ane Permatasari memberikan ide program yang layak dijalankan sebagai upaya membangun budaya baca masayarakat Indonesia (Permatasari, 2015), yaitu: 1) perlu memperbaiki kualitas dan pemerataan pendidikan agar bisa mendorong tingkat melek huruf yang lebih tinggi. Infrastruktur (fasilitas) dan suprastruktur (sumber daya manusia) perlu dikembangkan hingga menjangkau pelosok Tanah Air. Sehingga tidak ada masyarakat di pedalaman Nusantara sekalipun yang masih sulit belajar garagara tidak ada sekolah, kekurangan guru, atau minim fasilitas lain. Negara bertanggung jawab memenuhi fasilitas pendidikan bagi warganya. 2) bangun lebih banyak perpustakaan di semua daerah sebagai tempat yang nyaman untuk membaca, jumlah koleksi buku yang banyak, dan menawarkan kegiatan yang menarik. 3) dibutuhkan program-program berkelanjutan untuk lebih memperkenalkan buku dan mendorong minat baca buku ke sekolah dan masyarakat umum. 4) dari sisi penerbit, harus ada dorongan agar semakin banyak buku diterbitkan, terutama buku-buku yang berkualitas dari berbagai bidang. Kian banyak tawaran buku menarik, kian banyak alternatif bacaan bagi masyarakat, dan 5) dukung kekuatan masyarakat madani untuk bersama-sama pemerintah dan semua pihak membangun peradaban membaca buku.

Peran lembaga pendidikan khususnya Perguruan Tinggi untuk peka atas lemahnya pengembangan kemampuan membaca di masyarakat. Perguruan Tinggi dengan Tri Darmanya dapat memberikan solusi melalui kegiatan pengajarannya, berupa perbaikan kualitas atas pengajaran membaca di program studi calon guru (di PT LPTK), melalui kegiatan penelitian model, metode, strategi, pengembangan bahan ajar dan media pembelajaran untuk mengembangkan kemampuan membaca siswa dan juga masyarakat umum, dan terakhir melalui berbagai kegiatan pengabdian seperti sosialisasi dan pendampingan program literasi sekolah, pelatihan peningkatan pengajaran membaca, sosialisasi dan pendampingan tata kelola perpustakaan sekolah dan sebagainya.

Terakhir, perlu perbaikan peran serta masyarakat secara menyeluruh. Sebab sebaik apapun kebijakan dan regulasinya tapi tanpa dukungan masyarakat maka akan sia-sia, misal Gerakan Literasi Sekolah yang sudah hampir berusia 4 tahun. Hal yang bisa dilakukan misal menyebarluaskan kegiatan 18.00-21.00 di lingkungan masyarakat, membangun taman-taman bacaan masyarakat (TBM) di RT, RW atau Dusun/Kampung. Meskipun 3-4 tahun belakangan ini banyak bermunculan para relawan literasi di berbagai daerah yang sungguh sangat mengagumkan seperti: 1) Sururi penggerak kuda pustaka di daerah Purbalingga, Jawa Tengah (jateng.tribunnews.com, 2017), 2) M.Ridwan Alimuddin penggerak perahu pustaka di Mandar Sulawesi Barat (kompas.com, 2017a), 3) Fauzi penggerak literasi dengan berjualan jamu di daerah Sidoarjo Jawa Timur (kompas.com, 2017b), 4) Anton Wibowo yang berjualan otak-otak sambil meminjamkan buku di daerah Cilacap Jawa Tengah (merdeka.com, 2017) dan masih banyak lagi para sukarelawan yang secara personal membaktikan diri untuk membangkitkan gemar membaca dan budaya membaca di Indonesia. Jika mereka secara individu saja bisa melakukan, maka dapat dibayangkan jika sekumpulan masyarakat bergerak untuk memberikan kontribusi pada gerakan gemar membaca atau budaya membaca di daerah tempat tinggalnya, atau minimal setiap keluarga pada anggota keluarganya masing-masing, misalnya menyisihkan penghasilan untuk belanja buku (bagi yang mampu), membuat kegiatan membaca bersama atau mengalihkan kebiasan bermain gadget berupa games anak-anak di rumah pada kegiatan membaca. Kini berbagai aplikasi telah memfasilitasi hal ini contohnya aplikasi Ayo Membaca (lets Read) di Play Store yang dikembangkan oleh Asia Foundation (asiafoundation.org, 2017).

\section{SIMPULAN DAN SARAN}

Membaca adalah kemampuan mendasar setiap manusia yang hidup di masa kini apalagi masa mendatang. Kemampuan membaca kini tidak lagi terbatas pada sekedar menyusun huruf menjadi kata, membaca kata-kata menjadi sebuah kalimat, membaca kalimat per kalimat menjadi sebuah paragraf, dan membaca paragraf demi paragraf menjadi sebuah wacana. Membaca harus memahami makna dibaliknya dan mengarahkan perilaku si pembaca atas makna yang didapatkan dari bacaan yang telah diselesaikannya. Apalagi informasi di era sekarang kalimat-kalimat telah berganti menjadi visualisasi seperti gambar, grafik, poster, peta konsep, pemetaan dan sebagainya, yang tentu membutuhkan lebih dari sekedar membaca secara visual semata. Untuk itu menumbuhkan budaya membaca dan membekali keterampilan membaca pemahaman dengan orientasi berpikir tingkat tinggi pada setiap warga 
negaranya menjadi salah satu tantangan berat bangsa Indonesia kedepan. Motivasi meningkatkan kemampuan dan menumbuhkan budaya membaca harus digelorakan semangatnya pada bangsa Indonesia terutama pada para siswa sebagai modal utama mereka mempelajari berbagai ilmu pengetahuan dan menyerap berbagai informasi di era zama ini. Tentu semangat ini tidak sekedar ditujukan untuk sekedar menaikan ranking tingkat literasi membaca Indonesia di kancah internasional seperti PISA, PIRLS, EGRA dsb., tapi jauh lebih penting dari itu adalah ditujukan untuk menumbuhkan daya baca bangsa. Menyusun pola pembelajaran membaca dan penilaiannya agar sama dengan standar asesmen internasional sehingga harapannya mampu menaikkan peringkat Indonesia memang perlu dilakukan, namun jauh labih penting adalah menumbuhkan karakter dan budaya senang membaca pada generasi penerus bangsa jauh lebih utama. Seperti yang ditegaskan oleh Ibrahim bahwa:

\begin{abstract}
"Di atas segalanya, pembiasaan menjadi bangsa pembaca bukan hanya perkara menghitung nilai pencapaian setiap akhir belajar. Pembiasaan untuk keluar dari ketidaksabaran dan ketidakcermatan dalam membaca adalah proyek kebudayaan membaca; dan proyek kebudayaan membaca tidak bisa dikerjakan secara instan, kecuali kalau kita hanya ingin meningkatkan indeks dan peringkat literasi membaca kita. Memang, PISA adalah salah satu alat ukur seberapa jauh hasil belajar telah dicapai. Akan tetapi, jika cara-cara menumbuhkan budaya literasi membaca yang hanya untuk menaikkan peringkat, sesungguhnya kita sedang mendorong belajar bukan untuk mencapai kepandaian, melainkan belajar sekadar mendapatkan nilai rapor dan peringkat."(Ibrahim, 2017).
\end{abstract}

Beberapa saran yang perlu dilakukan sebagai upaya menumbuhkan budaya dan daya baca bangsa diantaranya: 1) merumus-ulang paradigma pembelajaran membaca, tidak hanya melalui mata pelajaran bahasa (Indonesia dan Inggris), tetapi menyusun model pembelajaran membaca bagi seluruh mata pelajaran, 2) perbaikan sarana prasarana perpustakaan sekolah yang diringi perbaikan tata kelola dan program kerja perpustakaan sebagai pusat literasi di semua jenjang sekolah, 3) meningkatkan kualitas proses pembelajaran melalui penerapan model, metode, strategi, pengembangan bahan ajar dan media pembelajaran untuk mengembangkan kemampuan membaca siswa terutama pada jenjang sekolah dasar, 4) perbaikan kualitas atas pengajaran membaca di program studi calon guru di lembaga pendidik tenaga kependidikan melalui kegiatan penelitian tentang model, metode, strategi, pengembangan bahan ajar dan media pembelajaran untuk mengembangkan kemampuan membaca siswa lalu disosialisasikan melalui program pengabdian kepada masyarakat khususnya sekolah-sekolah, 4) adanya program kemasyarakatan atau komunitas yang mendorong pada peningkatan kesadaran dan peran serta masyarakat secara menyeluruh tentang pentingnya budaya membaca seperti taman bacaan masyarakat, jam belajar dan sebagainya.

\title{
DAFTAR PUSTAKA
}

Aryani, S., Samadhy, U., \& Sismulyasih, N. (2012). Peningkatan Keterampilan Membaca Pemahaman Melalui Strategi Know-Want-Learned (KWL) Pada Siswa Kelas IVa SDN Sekaran 01 Semarang. Joyful Learning Journal, 1(1), 9.

asiafoundation.org. (2017). Let's Read-The Asia Foundation. Retrieved March 10, 2019, from https://asiafoundation.org/what-we-do/books-for-asia/lets-read/

Boliti, S. (2017). Peningkatan Kemampuan Membaca Pemahaman Siswa Kelas IV SDN 1 LumbiLumbia Melalui Metode Latihan Terbimbing. Jurnal Kreatif Tadulako, 2(2), 12.

BPS. (2017). Potret Pendidikan Indonesia Statistik Pendidikan 2017. Jakarta: Badan Pusat Statistik.

Central Connecticut State University. (2017). World's Most Literate Nations. Retrieved March 8, 2019, from Www.ccsu.edu website: http://www.ccsu.edu/wmln/rank.html

Driana, E. (2012, December 14). Gawat Darurat Pendidikan—Kompas.com [Newspaper]. Retrieved March 9, 2019, from Kompas.com website: https://nasional.kompas.com/read/2012/12/14/02344589/gawat.darurat.pendidikan

Fanani, A., \& Kusmaharti, D. (2018). PENGEMBANGAN PEMBELAJARAN BERBASIS HOTS (HIGHER ORDER THINKING SKILL) DI SEKOLAH DASAR KELAS V. Jurnal Pendidikan Dasar, 9(1), 11. 
Permasalahan Budaya Membaca di Indonesia (Studi Pustaka Tentang Problematika \& Solusinya) (Lilik Tahmidaten, Wawan Krismanto)

Harras, K. A. (2014). Hakikat dan Proses Membaca. In PBIN4108/MODUL 1 (p. 56). Jakarta: Universitas Terbuka.

Harsiati, T. (2018). KARAKTERISTIK SOAL LITERASI MEMBACA PADA PROGRAM PISA. LITERA, 17(1). https://doi.org/10.21831/ltr.v17i1.19048

Ibrahim, G. A. (2017, April 30). PISA dan Daya Baca Bangsa-Kompas.com [Newspaper]. Retrieved March 9, 2019, from Kompas.com website: https://nasional.kompas.com/read/2017/04/30/11135891/pisa.dan.daya.baca.bangsa

jateng.tribunnews.com. (2017, October 5). KISAH Sururi, Pemilik Kuda Pustaka Naik Turun Gunung Pinjami Buku yang Mendunia-Tribun Jateng. Retrieved March 10, 2019, from http://jateng.tribunnews.com/2017/05/10/kisah-sururi-pemilik-kuda-pustaka-naik-turungunung-pinjami-buku-yang-mendunia

Kemdikbud, D. D. (2016). Desain induk gerakan literasi sekolah. Jakarta: Dirjen Dikdasmen Kemdikbud.

Kemdikbud, P. (2017). Hasil Indonesian National Assesment Programme (INAP). Retrieved March 11, 2019, from Puspendik.kemdikbud.go.id website: https://puspendik.kemdikbud.go.id/inap-sd/

kompas.com. (2017a, February 5). Kisah Perahu Pustaka Jelajahi Pesisir Sulawesi agar Anak-anak Bisa Membaca Halaman all-Kompas.com. Retrieved March 10, 2019, from https://regional.kompas.com/read/2017/05/02/21202801/kisah.perahu.pustaka.jelajahi.pesisir. sulawesi.agar.anak-anak.bisa.membaca?page $=$ all

kompas.com. (2017b, August 5). Kisah Fauzi dari Jual Jamu Sambil Bawa Buku hingga Bangun Rumah Baca. Retrieved March 10, 2019, from KOMPAS.com website: https://regional.kompas.com/read/2017/05/18/07000081/kisah.fauzi.dari.jual.jamu.sambil.baw a.buku.hingga.bangun.rumah.baca

Krismanto, W., Halik, A., \& Sayidiman, S. (2015). Meningkatkan Kemampuan Membaca Pemahaman Melalui Metode Survey, Question, Read, Recite, Review (SQ3R) Pada Siswa Kelas IV SD Negeri 46 Parepare. Publikasi Pendidikan: Jurnal Pemikiran, Penelitian dan Pengabdian Masyarakat Bidang Pendidikan, 5(3).

Krismanto, W., Halik, A., \& Sayidiman, S. (2015). Meningkatkan Kemampuan Membaca Pemahaman Melalui Metode Survey, Question, Read, Recite, Review (SQ3R) Pada Siswa Kelas IV SD Negeri 46 Parepare. Publikasi Pendidikan: Jurnal Pemikiran, Penelitian dan Pengabdian Masyarakat Bidang Pendidikan, 5(3).

merdeka.com. (2017, June 19). Kisah inspiratif pedagang otak-otak bikin rental buku gratis | merdeka.com. Retrieved March 10, 2019, from https://www.merdeka.com/peristiwa/kisahinspiratif-pedagang-otak-otak-bikin-rental-buku-gratis.html

Mullis, I. V. S., \& Martin, M. O. (2017). PIRLS 2016 International Results in Reading. Chestnut Hill, MA 02467 United States: TIMSS \& PIRLS International Study Center, Lynch School of Education, Boston College.

Noriasih, N. K. (2013). PENGARUH MODEL PEMBELAJARAN RECIPROCAL TEACHING TERHADAP PEMAHAMAN BACAAN DITINJAU DARI KONSEP DIRI AKADEMIK SISWA. Jurnal IKA, 11(2), 19.

OECD. (2018). Indonesia-Country Note - Results from PISA 2015 (p. 8). Retrieved from OECD website: www.oecd.org/pisa

Permatasari, A. (2015). MEMBANGUN KUALITAS BANGSA DENGAN BUDAYA LITERASI. Prosiding Seminar Nasional Bulan Bahasa UNIB 2015, 146-156. Universitas Bengkulu: Universitas Bengkulu.

Rahim, F. (2008). Pengajaran Membaca di Sekolah Dasar. Jakarta: Sinar Grafika. 
Sari, N. P., Winarni, R., \& Daryanto, J. (2014). PENINGKATAN KEMAMPUAN MEMBACA INTENSIF DENGAN MENGGUNAKAN PENDEKATAN SOMATIC, AUDITORY, VISUAL, AND INTELLECTUAL (SAVI). Jurnal Didaktika Dwija Indria, 10(1), 5.

Setiyaningsih, G., \& Syamsudin, A. (2019). Pengembangan Media Big Book Untuk Meningkatkan Kemampuan Literasi Anak Usia 5-6 Tahun. Scholaria: Jurnal Pendidikan Dan Kebudayaan, 9(1), 19-28.

Tarigan, H. (2008). Membaca sebagai Suatu Keterampilan Berbahasa. Bandung: Angkasa.

Tristiantari, N. K. D., \& Sumantri, I. M. (2017). MODEL PEMBELAJARAN COOPERATIF

Tristiantari, N. K. D., \& Sumantri, I. M. (2016). Model pembelajaran cooperatif integrated reading composition berpola lesson study meningkatkan keterampilan membaca dan menulis. JPI (Jurnal Pendidikan Indonesia), 5(2), 203-211.

(USAID) Indonesia. (2014). Indonesia 2014: The National Early Grade Reading Assessment (EGRA) and Snapshot of School Management Effectiveness (SSME) Survey; Report of Findings (No. AID-497-BC-13-00009; p. 81). United States Agency for International Development.

Widiningsih. (2019). Modul Penyusunan Soal Keterampilan Berpikir Tingkat Tinggi. Jakarta: Direktorat Pembinaan Sekolah Menengah Atas Direktorat Jenderal Pendidikan Dasar Dan Menengah Kementerian Pendidikan Dan Kebudayaan. 